Received Date : 13-May-2016

Accepted Date : 11-Jul-2016

Article type : Primary Research Articles

\title{
Spatial and temporal dimensions of fire activity in the fire-prone eastern
}

\section{Canadian taiga}

Running head: Taiga fires across space and time

Sandy Erni ${ }^{1}$, Dominique Arseneault ${ }^{2,5}$, Marc-André Parisien ${ }^{3}$, Yves Bégin ${ }^{4}$

1. Centre Eau Terre Environnement, Institut national de la recherche scientifique, 490, rue de la Couronne, Québec (Québec) Canada, G1K 9A9. sandy.erni@ outlook.com

2. Département de biologie, chimie et géographie, Centre d'Études Nordiques, Université du Québec à Rimouski, 300, allée des Ursulines, Rimouski (Québec) Canada, G5L 3A1.

3. Northern Forestry Centre, Canadian Forest Service, Natural Resources Canada, Edmonton, Alberta, Canada, T6H 3S5. marc-andre.parisien@ canada.ca

4. Institut national de la recherche scientifique, 490 de la Couronne, Québec, Qc, Canada, G1K 9A9. yves.begin@inrs.ca

5. Corresponding author: Dominique Arseneault; Tel: (418) 723-1986 ext 1519; Fax: (418) 724-1849; email: dominique_arseneault@uqar.ca

This article has been accepted for publication and undergone full peer review but has not been through the copyediting, typesetting, pagination and proofreading process, which may lead to differences between this version and the Version of Record. Please cite this article as doi: $10.1111 / \mathrm{gcb} .13461$

This article is protected by copyright. All rights reserved. 
Keywords : Extreme weather, Fire-free intervals, Fire size, Fire overlaps, Fuel feedback, Predictability of boreal forest-age mosaics, Top-down vs. bottom-up drivers of fire activity, Natural range of variability

\section{Abstract:}

The forest-age mosaic is a fundamental attribute of the North American boreal forest. Given that fires are generally lethal to trees, the time since last fire largely determines the composition and structure of forest stands and landscapes. Although the spatiotemporal dynamics of such mosaics has long been assumed to be random under the overwhelming influence of severe fire weather, no long-term reconstruction of mosaic dynamics has been performed from direct field evidence. In this study, we use fire length as a proxy for fire extent across the fire-prone eastern Canadian taiga and systematically reconstruct the spatiotemporal variability of fire extent and fire intervals, as well as the resulting forest age along a 340-km transect for the 1840-2013 time period. Our results indicate an extremely active fire regime over the last two centuries, with an overall burn rate of $2.1 \%$ of the land area $\mathrm{yr}^{-1}$, mainly triggered by seasonal anomalies of high temperature and severe drought. However, the rejuvenation of the age mosaic was strongly patterned in space and time due to the intrinsically lower burn rates in wetland-dominated areas and, more importantly, to the much-reduced likelihood of burning of stands up to 50 years postfire. An extremely high burn rates of $\sim 5 \% \mathrm{yr}^{-1}$ would have characterized our study region during the last century in absence of such fuel age effect. Although recent burn rates and fire sizes are within their range of variability of the last 175 years, a particularly severe weather event allowed a 2013 fire to spread across a large fire refuge, thus shifting the abundance of mature and old forest to a historic low. These results provide reference conditions to evaluate the significance and predict the spatiotemporal dynamics and impacts of the currently strengthening fire activity in the North American boreal forest. 


\section{Introduction}

The North American boreal forest is strongly shaped by extensive and recurrent wildfires (Payette et al., 1989; Payette, 1992; Stocks et al., 2002; Boulanger et al., 2012). These fire occur under the compounded influence of several top-down and bottom-up drivers (Parisien et al., 2011; Cavard et al., 2015; Dash et al., 2016), such as ignition agents (Flannigan \& Wotton, 1991), weather conditions before and during fire spread (Flannigan \& Wotton, 2001; Wang et al., 2014), fuel composition and loading (Hély et al., 2010; Héon et al., 2014; Parisien et al., 2014), and landscape physiography (Mansuy et al., 2014). Because most fires are stand replacing (Rogers et al., 2015), boreal landscapes are structured as mosaics of large even-aged forest patches (White \& Pickett, 1985). After burning, patches undergo a postfire trajectory of vegetation succession and biomass accumulation until complete or partial destruction by the subsequent fire (Brown \& Johnstone, 2011).

Consequently, the time since the last fire is an important attribute that determines forest composition and structure and carbon stocks at both stand and landscape levels (Bond-Lamberty et al., 2004, 2007; Taylor and Chen, 2011; Irulappa Pillai Vijayakumar et al., 2016).

Models suggest that the North American boreal forest will experience a generalised increase of burn rates (percent area burned annually) during the 21 st century as a consequence of projected climatic changes (Flannigan et al., 2005; Balshi et al., 2009; Bergeron et al., 2011; Boulanger et al., 2014; Wang et al., 2015). Larger fires, on average, and more frequent large-fire years are predicted (Kasischke \& Turetsky, 2006; Ali et al., 2012), with associated impacts on the spatial structure and functioning of the landscape age mosaic (Bond-Lamberty et al., 2007; Johnstone et al., 2011; Kettridge et al., 2015). Indeed, fire activity has already increased during the last 30 years in some areas of the boreal forest and adjacent tundra (Kasischke \& Turetsky, 2006), a phenomenon that may have triggered 
shifts to more fire-prone and less-productive ecosystems, as well as to reduced carbon stocks (Lavoie \& Sirois, 1998; Johnstone et al., 2010; Mack et al., 2011; Turetsky et al., 2011). In fact, the projected fire activity is unlikely to maintain forest cover in several of the most fireprone areas, thereby causing a shift to woodland or nonforest vegetation (Westerling et al., 2011).

However, most projections of future fire activity are based on climate only and assume no negative feedback of stand age on fire activity (Flannigan et al., 2005; Balshi et al., 2009; Bergeron et al., 2011; Boulanger et al., 2014). Although fire activity has long been considered independent from forest age in the North American boreal forest (Bessie \& Johnson, 1995), strong support for an age effect has recently emerged from the monitoring of fire perimeters (Parisien et al., 2014; Bernier et al., 2016; Dash et al., 2016), as well as from exhaustive datasets of fire overlaps over the last few centuries (Niklasson and Granström, 2000; Héon et al., 2014). This age effect has also been documented from various regions around the world, such as the western United States, Portugal and Australia, although the intensity of this phenomenon varies with fire frequency (i.e. encounter rate between new and previous fires), forest types and weather severity (O’Donnell et al., 2011; Price et al., 2010, 2015; Parks et al., 2015, 2016). In the context of climate change, such an age effect would lead to landscape age mosaics with very different properties relative to the age-independent scenario (Fig. 1). First, because the likelihood of re-burning increases with stand-age, the youngest fraction of the mosaic would reduce fire spread across the landscape and would buffer the predicted increase of burn rates. Second, because the age feedback spatially structures the likelihood of burning, the age effect would increase the predictability of fire occurrence across the mosaic. In theory, this buffering and enhanced predictability of the fire activity would increase with the strength of the age effect. 
Yet, because stand-age mosaics are continuously reshaped, evaluating how actual landscapes diverge from the age-dependent scenario is challenging. Understanding the dynamics of landscape age mosaics requires systematic data on past fire sizes and fire intervals across an area larger that the largest possible fire over a time period longer that the mean fire interval, whereas most fire reconstructions document fire across either the temporal or the spatial dimension, but rarely both aspects. For example, charcoal analysis from sediments provides records of past fire intervals over millennia at given sampling points (Ali et al., 2012; Kelly et al., 2013, Oris et al., 2014) without direct measurement of fire size across space.

Conversely, reconstructing the time since the last fire across space documents the size of the most recent fire events (Bergeron et al., 2004) without direct measurement on fire intervals through time.

To overcome the shortcoming or fire reconstructions not having both temporal and spatial depth, a method has been developed in which fire length is used as a proxy for fire extent. With this method, it has been possible to reconstruct past fire overlaps along a 190-km road transect across the fire-prone eastern Canadian taiga (Héon et al., 2014). This approach allowed a detailed depiction of both fire extents and associated fire intervals over the last two centuries, and was used to document a negative feedback between stand age and the probability of burning. In the present study, we expanded this dataset by sampling an additional $150 \mathrm{~km}$ to the south. The resulting 340-km transect covers a geographic gradient of increasing fire size, from south to north, as well as the last 175 years of fire activity (1840$2013)$ in a region characterized by rapid recent warming $\left(0.5^{\circ} \mathrm{C}\right.$ increase in mean June-July temperature per decade since 1975; CRU TS 3.21 dataset; Harris et al., 2014).

This article is protected by copyright. All rights reserved. 
The main goal of this study is to use the above-mentioned dataset to reconstruct the spatiotemporal variability of the stand-age mosaic and investigate the effect of its main topdown and bottom-up drivers. Specifically, we evaluate to what extent the landscape age mosaic has diverged from the age-independent scenario in one of the most fire-prone areas of the North American boreal forest. In doing so, our study also addresses the following questions: i- have the burn rate and response to climate change been buffered by the standage feedback? ; i-has the warming trend of the last 40 years led to unprecedented fire activity and novel forest-age mosaics in the context of the last two centuries ; iii- what is our ability to identify areas at high risk of burning across the mosaic? Results will provide reference conditions for evaluating fire impacts on ecosystems and infrastructures over the coming decades.

\section{Materials and Methods}

Study area

The study transect spans $340 \mathrm{~km}$ along the Bay James Road (built in 1971-1972) from north $\left(53^{\circ} 3^{\prime} \mathrm{N}\right)$ to south $\left(51^{\circ} 2^{\prime} \mathrm{N}\right)$ around $77^{\circ} 3^{\prime} \mathrm{W}$ (Fig. 2), in the province of Quebec. This region is characterized by a succession of low hills and depressions, made of the gneissic and granitic rocks of the Canadian Precambrian Shield, and forms a regular plateau varying between 100 to 200 meters above sea level (Stockwell et al., 1968). Numerous lakes and rivers compose a dense hydrographic network flowing to James Bay. Peatlands are abundant, covering about $10-20 \%$ of the landscape. The climate is low sub-arctic with a mean annual air temperature varying between $-3.1^{\circ} \mathrm{C}$ to $-2.4^{\circ} \mathrm{C}$ from north to south, the coldest and the warmest months being January and July, respectively. The average annual precipitation is $683 \mathrm{~mm}, 40 \%$ of which falls as snow between October and May (Environment Canada, 2016).

This article is protected by copyright. All rights reserved. 
The region experiences one of the most active fire regimes and some of the largest recorded fires of the North American boreal forest. Burn rates have averaged $2.4 \%$ of the land area per year over the last century and fires larger than $90 \mathrm{~km}$ in length have recurred every 20-30 years (Boulanger et al., 2013; Héon et al., 2014). Detailed fire perimeters of the last 35 years indicate that fire sizes increase from south to north, to the point where the northern half of our sampling transect intersects two of the three largest fires recorded in Canada over the 1980-2013 period (Fig. 2), including the 2013 Eastmain fire $\left(5830 \mathrm{~km}^{2}\right)$.

The fire season spans from May to September, although most fires occur in June and July. Wildfires are mostly ignited by lightning and there is virtually no fire suppression beyond the immediate vicinity of municipalities and hydroelectric facilities, nor is there any logging or agriculture, allowing us to document a largely natural fire regime. Human ignitions have been responsible for less than 3\% of the total area burned since 1973 (Canadian Forest Service, 2016). Black spruce (Picea mariana (Mill.) B.S.P.) and jack pine (Pinus banksiana Lamb.) dominate the landscape. Both species are fire adapted and regenerate quickly after fire from aerial seedbanks stored in their serotinous cones (St-Pierre et al., 1992; Sirois, 1995). Eastern larch (Larix laricina (Du Roi) K. Koch) is frequent but rarely dominant. Broadleaved taxa are rare, covering less than $5 \%$ of the landscape.

Field sampling

Even if North American boreal fires are generally stand replacing, numerous surviving trees develop fire scars at the margin of unburned forest patches or within less severely burned areas. Thus, by systemically sampling fire scars and establishment dates of trees into a series of contiguous and sufficiently large cells along a road transect, it is possible to reconstruct the length intersected by each fire that spread across the transect (hereafter "fire 
length") during the last two centuries (Héon et al., 2014). In their study, Héon et al. (2014) sampled 93 cells of $\sim 2 \mathrm{~km}$ x $1 \mathrm{~km}$ along a 193-km transect between the Eastmain and La Grande rivers along the James Bay road. Using the same method, we extended this transect by an additional $150 \mathrm{~km}$, thus sampling 75 new $2-\mathrm{km}^{2}$ cells (Fig. 2).

Within each cell, we exhaustively surveyed areas of potentially low rate of fire spread (stream, lake and peatland margins; rocky outcrops; topographic breaks; uneven or open forest stands) to sample fire scars and establishment date of trees (trunk cross-section) on live trees, snags, or woody debris. Large stems with multiple scars were always preferred over isolated scars as they are more likely to record short fire intervals. We also systematically favoured jack pine over black spruce or eastern larch stems due to its more rapid postfire regeneration, faster juvenile height growth, and its proneness to develop multiple scars. Tree stems were sampled into each cell (average of 13 stems per cell) with the goal of obtaining duplicates of as many different fire dates as possible over the last two centuries. In order to optimize sampling, fire intervals were estimated in the field from tree ring counts on stems cross sections; each sample suggesting a new fire date was brought to the lab whereas those indicating an already duplicated fire date were disregarded. For each sample, we recorded the species, the sampling height, stem type (living, snag, woody debris), stump type (attached to the trunk or not), and GPS location.

A 20-km section in the center of the transect ( $\mathrm{km}$ 220-240) was occupied by old black spruce stands (>300-400 years old) with rare or absent jack pine trees and few or no fire scars. In this section, three dominant black spruce stems were sampled at the root collar on at least two hilltops in each cell in order to estimate minimum stand age. This strategy was also applied locally between km 294-302 and km 316-340 of the transect (Fig. S1) in order to 
reconstruct $19^{\text {th }}$-century fires because these two sections comprised only relatively recent (>1835 and >1900, respectively) jack pine material.

In the laboratory, each cross section was finely sanded so that tree rings and fire scars could be distinguished under a binocular microscope. We dated fire scars from living trees by counting tree rings from the sampling year, considering also diagnostic light rings as a validation tool. Scars from dead trees and from trees with suppressed growth sequences were first crossdated from a master chronology. Ring widths were measured and crossdated using Past4 (SCIEM, 2011) and COFECHA (Holmes, 1983). Fire dates where also deduced from establishment dates of live or dead pine trees that contained a trunk cross section with pith at a sampling height of less than one meter on stems with an attached stump. Following Héon et al. (2014), the establishment date at root collar was estimated from the first tree ring at sampling height, after adding a correction for the time lag between these two levels: $\mathrm{C}=$ $0.1154 \mathrm{H}$, where $\mathrm{C}$ is the correction (years) as a function of the sampling height $\mathrm{H}(\mathrm{cm})$.

\section{Data Analysis}

We applied some rules to reconstruct the sequence of fire years into each sampling cell (Fig. S1). First, each fire date had to be replicated by at least one scar or one corrected establishment date from the same cell or from one of the two adjacent cells. Fire years from establishment dates and scars were assigned to the same fire year if they formed a continuous sequence along the transect. Second, fire events only documented from establishment dates (i.e., no available scars) received the date of the oldest available tree ring from the corresponding sample ensemble. The dataset from the first $193 \mathrm{~km}$ at the northern end of the transect is considered to be complete for the period 1810-2013 (Héon et al., 2014). However, very few fire scars or basal samples from pine trunks could be found predating a large 1847 
fire at $\mathrm{km} \mathrm{234-298} \mathrm{in} \mathrm{the} \mathrm{southern} \mathrm{extension} \mathrm{of} \mathrm{the} \mathrm{transect.} \mathrm{Consequently,} \mathrm{we} \mathrm{retained} \mathrm{the}$ period 1840-2014 for analysis along the entire transect. Nonetheless, fire dates earlier than 1840 were considered for determining the time elapsed between the corresponding fire and the next subsequent fire (beyond1840) in the same cell. In this study, we considered a total of 2062 dead or living trees sampled in the 166 cells of the transect, including 1196 trees sampled by Héon et al. (2014) (Table S1). These samples provided 3197 fire dates from 1834 fire scars and 1363 establishment dates (Table S1). Because only two fire dates need to be found per $4 \mathrm{~km}^{2}$ to confirm a fire date within a cell (i.e. a scar or establishment date within a given cell or one of the two adjacent cells), we believe that exhaustive and repeated surveys of each cell allowed most fire to be detected.

Using fire years within sampling cells, we computed fire length (total distance burned during each fire year), fire-free intervals (FI; number of years between each pair of consecutive fire years within each cell), and time since previous fire (TSF; number of elapsed years since the previous fire year) of the 1840-2014 time period in each cell. In order to emphasize longitudinal patterns of fire activity, the entire transect was subdivided into three homogeneous sections, northern, central and southern, based on contrasted patterns of fire lengths, fire intervals and forest composition (Fig. 3a and S1 and Table 1). Although the northern $(\mathrm{km} 0$ - 210) and southern $(\mathrm{km} 238$ - 340) sections have experienced similarly short fire intervals, fires were much longer in the north. In contrast, the central section $(\mathrm{km} 210$ 238) has been characterised by very long intervals along with the absence of the firedependent jack pine (Fig. S1), and was thus considered as a fire refuge sheltered from recurrent fires. For each year, we then computed the relative abundance ( $\%$ of transect length) of nine successive TSF classes $(0-10,11-20,21-30,31-40,41-50,51-60,61-70,71-100,>100$ years since previous fire) for the transect sections and the entire transect. 
Burn rates (percent land area burned per year) were computed for selected time periods and the northern and southern sections by summing all distances burned and dividing by the duration of the time period of interest (the central section was excluded because of its short length and low fire occurrence). Burn rates were also computed by age classes (1-20, 21-40, $41-60,61-80,>80$ years) for the northern and southern sections and for selected time periods. To accomplish this, we divided FI by TSF frequencies within each class, as these values represent the distance (number of cells) that burned for a given age relative to the distance available to burn, respectively (Héon et al., 2014). Confidence intervals of the FI/ TSF ratio were estimated by bootstrapping. For each age class, the FI/TSF ratio was computed 10000 times from random samples of the original data, and the $95 \%$ confidence limits were estimated from the $2.5 \%$ and $97.5 \%$ percentiles. Burn rates computed from fire lengths are similar to rates computed from the surface area of fire polygons (Héon et al., 2014).

Because wet areas are known to influence fire spread and fire recurrence (Hellberg et al., 2004; Senici et al., 2015), we verified if the number of fire events detected in each cell decreased with increasing abundance of peatlands and lakes in areas surrounding cells. The number of fire recorded in each cell during the 1840-2014 period was compared to the cover of wet areas (lakes plus peatlands) within buffers of $2.5 \mathrm{~km}$ from the centroid of cells. Larger buffers were not considered as they imply strong autocorrelation between successive cells. Peatland and lake cover areas were obtained from governmental digital maps at scale 1:50 000 (Natural Resources Canada, 2006). We grouped cells by the number of detected fire events ( $\mathrm{n}$ fires $=1-2,3-4,5-6,7-8$ ) and compared the median cover of wet areas among groups. For each group, the median area was computed 10000 times from random samples of the original data, and the $95 \%$ confidence limits were estimated from the $2.5 \%$ and $97.5 \%$ percentiles.

This article is protected by copyright. All rights reserved. 
Effects of weather and climate on fire spread and length burned were analysed for two spatio-temporal domains. First, for the northern and southern transect sections, we used superposed epoch analysis along with the gridded CRU TS 3.21 dataset (1901-2012; Harris et $a l ., 2014)$ to verify if fire years of the 1901-2012 time period have been characterized by significant anomalies of monthly mean maximum temperature (MTmax), monthly total precipitation (MPcp), and Monthly Drought Code (MDC) for the months of May, June, July, as well as the combination of June and July. More than $95 \%$ of the total area burned between 1980 and 2013 in our study region corresponds to fires ignited during these three months. We averaged 36 cells of the CRU dataset between $51^{\circ}$ and $54^{\circ} \mathrm{W}$ and $75.5^{\circ}$ and $78.5^{\circ} \mathrm{N}$. We performed the analysis separately for large fire years (total length burned $\geq 10 \mathrm{~km} ; \mathrm{n}=16$ ) and less important fire years $(<10 \mathrm{~km} ; \mathrm{n}=16)$. The MDC, which is computed from MTmax and MPcp, is a monthly version of the Drought Code of the Canadian Fire Weather Index System and is a good predictor of the area burned annually during the last $30-40$ years across the Canadian boreal forest (Girardin \& Wotton, 2009). Confidence intervals ( $\mathrm{P}=0.05$ and 0.01) of the superposed epoch analysis were determined by bootstrapping.

Second, the 2013 Eastmain fire burned for 5 weeks under an array of weather and landscapes conditions and offered us an exceptional opportunity to examine the bottom-up and top-down controls on the fire as it was developing. We thus compared the map of daily fire progression built from MODIS data (Parks, 2014) with time series of the Canadian Forest Fire Weather Index (FWI) during the 2013 fire season. The FWI combines values of temperature, relative humidity, and wind speed at noon, and 24-h precipitation to evaluate potential fire intensity, with higher values indicating greater fire danger (Van Wagner, 1987).

We also examined the entire daily FWI record from the La Grande weather station (19772013; $\mathrm{n}=6147$ days) to verify if the 2013 fire weather was unprecedented. 


\section{Results:}

Length burned and fire intervals in space and time

High burn rates and large fires have characterised most of the study transect since 1840

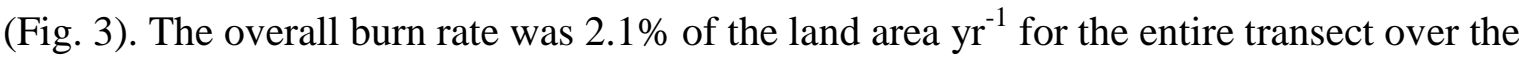
1840-2013 time period. In total, fires have intersected the transect over a cumulated length of $1242 \mathrm{~km}$, including $372 \mathrm{~km}$ in 1840-1910 (1.1 times the transect length) and $870 \mathrm{~km}$ in 1911 2014 (2.6 times the transect length). The ten most important fire years were $1922(124 \mathrm{~km})$, 2013 (99 km), 1989 (96 km), 1941 (95 km), 1847 (84 km), 1972 (80 km), $1916(64$ km), $2005(49 \mathrm{~km}), 1854(45 \mathrm{~km})$, and $1983(40 \mathrm{~km})$. Together these major fires intersected 775 $\mathrm{km}$ and corresponded to $62.4 \%$ of the total length burned since 1840 (Fig. S2). Similarly, fire years with length greater than $10 \mathrm{~km}(\mathrm{n}=25)$ intersected $1118 \mathrm{~km}$ and corresponded to $90 \%$ of the total distance burned.

From 1840 to 2013, a fire occurred on average every 3.5 years somewhere along the transect (Fig. 3a). Considering the entire transect, time intervals between successive fire years varied between one year (12 instances) and 10 years (1926-1936). Individual cells have recorded between 1 and 8 fire events and an average of 3.7 \pm 1.5 (mean \pm SD) fires per cell. Fire-free intervals within individual cells have varied between 2 years (1852-1854 and 19391941) and >308 years (1701-2013), this latter value being underestimated due to the absence of fire scars and pine stems across the five corresponding cells (cells 15, 16, 18, 19, 22; Fig. S1). In total, $58 \%$ and $26 \%$ of the cellwise fire-free intervals that ended after 1840 were shorter than 50 years and 25 years, respectively, and only $10 \%$ exceeded 100 years (Fig. S2).

The northern section has experienced much larger fires than the southern section during the $20^{\text {th }}$ century, as reflected in the mapped fire perimeters of the 1980-2013 time period (Fig. 2). Five fire years intersected the road transect over more than $50 \mathrm{~km}$ in the northern section 
after 1920, compared to none in the southern section (Fig. 3b). The large fire years of the $20^{\text {th }}$ century in the northern section were more regularly spaced in time than the shorter fires of the southern section, which were mainly clustered during the 1910-1930 and 1990-2010 time periods (Fig. 4a, b). The largest fire year of the $19^{\text {th }}$ century (1847) occurred mainly in the southern section, this fire being the only one that exceeded $50 \mathrm{~km}$ over the entire transect before 1922, suggesting that the two sections have experienced less contrasted fire sizes during the $19^{\text {th }}$ century.

Fire years were mostly asynchronous and length burned annually was not correlated (r $=-0.08$ ) between the northern and southern sections (Fig. S3). Of the 50 fire years recorded along the transect, only 12 were common to both the northern and southern sections. Nevertheless, when considering the total distance burned per 25-year time periods, the southern and northern sections have experienced remarkably synchronous trends of high burn rates since 1840 , including an abrupt increase from $\sim 1 \% \mathrm{yr}^{-1}$ to $\sim 3 \% \mathrm{yr}^{-1}$ around 1920 , and peaks of $\sim 4 \mathrm{yr}^{-1}$ around 1940 and 2010 and depressions of $\sim 1 \% \mathrm{yr}^{-1}$ around 1910 and 1970, respectively (Fig. 4d). In these two sections, the recent increase in burn rate is thus included within the range of variability of the 1840-2013 time period, though nearing its upper limit. In contrast, the intervening central section has been characterised by an almost complete absence of fire before the 2013 Eastmain fire, which intersected $88 \%$ of the section (Fig. 3a). Overall, the central section experienced a mean burn rate of $0.8 \% \mathrm{yr}^{-1}$, but this rate fall to $0.3 \% \mathrm{yr}^{-1}$ when excluding the 2013 fire.

Climate and weather

At the inter-annual scale, superposed epoch analysis reveals that large fire years (length burned $\geq 10 \mathrm{~km}$ ) are significantly associated with summer temperature and drought anomalies. Large fire years have been characterized by higher June, July and June-July 
temperatures and MDC than the preceding or following five years in the northern and southern sections (Fig. 5). In contrast, precipitations anomalies were significantly associated with large fire years only in the northern section for the month of June and June-July (Fig. S4). Less important fire years (length burned $<10 \mathrm{~km}$ ) were characterised by average temperature, precipitation, and drought conditions along the entire transect (Fig. S5).

During the 2013 Eastmain fire, extreme daily fire weather, in conjunction with fuel age, was a strong determinant of area burned (Fig. 6). The fire was ignited by lightning on June 9, 2013 and progressively expanded within a large area of forest stands older than 40 years during an episode of moderate-to-high FWI values until July 2. During the last few days of this sequence, the northern border of the fire perimeter was apparently constrained by the adjacent very large 1989 fire (fuels then 24 years of age; Fig 6b). Subsequently, during July 3-4 the fire grew extremely rapidly $\left(2348 \mathrm{~km}^{2}\right.$ in $\left.48 \mathrm{hrs}\right)$ under the $8^{\text {th }}$ and $10^{\text {th }}$ most extreme daily FWI values of the 1977-2015 period recorded at the La Grande weather station (Figs 6c and S6). These high FWIs resulted from high temperatures $\left(26-28{ }^{\circ} \mathrm{C}\right.$ at noon), as well as strong winds (mean speed of $33 \mathrm{~km} / \mathrm{hr}$ ) and low precipitation during the previous month (34.6 $\mathrm{mm}$ since June $5^{\text {th }}$, as compared to the June normal of $65.3 \mathrm{~mm}$ ). During these two days, the fire re-burned the 1989 fire to the north, as well as part of the 2005 fire (fuel age: 8 years) to the southeast, and spread across the fire refuge of the central section. The fire was extinguished by rain on July 10 (25 $\mathrm{mm}$ recorded at La Grande).

\section{Bottom-up drivers}

The strong negative feedback already observed between burn rates and fuel age for the first $193 \mathrm{~km}$ of the northern section (Héon et al., 2014) also apply to the southern section (Fig. 7a), despite difference in average fire size, number of fires, and fire years between these 
two sections. Burn rates progressively increase from about $1.3 \% \mathrm{yr}^{-1}$ in forest stands less than 20 years old to more than $5 \% \mathrm{yr}^{-1}$ in stands older than 50 years for the period 1910-2014 and 1840-2014 in the northern and southern sections, respectively. However, age-specific burnrates have been higher in young stands ( $<50$ years) of the northern section than the southern section during the $20^{\text {th }}$ century.

In addition to the bottom-up effect of stand age, the number of fires recorded per cell decreases with increasing wet areas in buffers of $2.5 \mathrm{~km}$ around cells (Fig. 7b). Cells surrounded by $5-12 \%$ of wet areas tended to experience between 5 and 8 fires, as compared to 1-2 fire events for cells surrounded by $16-26 \%$ of wet areas. These latter cells are concentrated into the central section, which cover $8.2 \%$ of the total transect length, but contains $42 \%$ of all cells that recorded 1-2 fires. In the central sections $100 \%$, of all cells recorded 1-2 fires and 2.5-km buffers around cells comprise $24 \%$ of wet areas.

Spatio-temporal variability of the stand age mosaic

The forest age mosaic has been highly variable in space and time. Although a high frequency of small fire years maintained a relatively stable age structure in the northern section prior to 1920 , large fires every 20-30 years subsequently generated large temporal variations in forest age (Fig. 4a). The northern section was successively dominated (40-60\% of the section length) by forest stands aged 1-10 years (in 1930, 1950, 1995), 11-20 years $(1935,1955,2005)$, and $21-30$ years $(1965,2000)$. In comparison, the grouping of smaller fires within the 1847-1864, 1910-1930, and 1990-2010 fire episodes in the southern section generated slower age structure fluctuations with age classes of less than 70 years successively peaking every 60-80 years (Fig. 4b). 
Even though the study transect was dominated by young forest, with stands $<50$ years old covering $58.4 \% \pm 8.6 \%$ and $76.2 \% \pm 7.4 \%$ of the transect length over the $1840-1919$ and 1920-2013 time periods, respectively, old-growth forest stands (>100 yrs old) had persisted in the fire refuge of the central section before the 2013 Eastmain fire (Fig. 4c, 8). Indeed, the forest age along the transect for years following the most important fire years indicates that the Eastmain fire shifted the overall age mosaic outside its range of variability of the last 175 years (Fig. 8). The fire almost entirely burned the last remaining old-growth forest patch that had escaped fire in the central section since at least the early $19^{\text {th }}$ century, such that only three cells greater than 100 years old (established after the 1847 fire at km 236-240 and the 1882 fire at km 12-14; $1.8 \%$ of the transect length) remain today. Moreover, forest stand older than 70 years are also near their minimum for the last 175 years (currently $15.1 \%$ of the transect length vs. minimum of $9.8 \%$ in 1973-1976) such that, even with a complete absence of fire, at least 25 years will be needed for the re-emergence of a near-average fraction $(10.5 \%)$ of forest stands older than 100 years. The longest remaining patch of mid-to-late successional forest is currently 74 years old (established after the 1941 fire) and covers $8.3 \%$ of the transect at its northern end ( $\mathrm{km} \mathrm{0-28).}$

\section{Discussion:}

Our sampling design allowed the fire activity and associated landscape age mosaic to be reconstructed from direct field evidence within a spatiotemporal domain of $340 \mathrm{~km}$ and 174 years, with resolutions of $2 \mathrm{~km}$ and 1 year, respectively. Each fire event detected was explicitly located within this domain, thus allowing the variability of fire lengths and fire intervals, as well as the resulting forest age, to be reconstructed across space and time. Our results indicate that this part of the eastern Canadian taiga has been characterised by an extremely active fire regime and a variable stand-age mosaic that has strongly diverged from 
the age-independent scenario of a randomly structured landscape (Fig. 1). Specifically, previous fires and wet areas strongly controll the regional fire activity across space and time such that burning young forests and areas fragmented by wetlands and lakes had to be triggered by severe drought and weather events, as was the case with the exceptional 2013 Eastmain fire. These results help understand and predict the dynamics and impacts of the currently strengthening fire activity in the North American boreal forest.

Structured vs. random age mosaic

Our exhaustive record of fire lengths allowed us to compare fire activity and monthly climate data over a period of 112 years. Anomalies of summer drought severity and high temperatures have been important top-down driver of area burned annually along the entire transect, mainly through their influence on the development of large fires (i.e. fire length greater than $10 \mathrm{~km}$ ), which accounted for $90 \%$ of the total distance burned during the last 175 years. This dominant role of temperatures and drought in our study area is coherent with most studies of fire activity in the North American boreal forest, although the relative influence of these two factors varies among regions (Duffy et al., 2005; Flannigan et al., 2005; Balshi et al., 2009; Parisien et al., 2011; Ali et al., 2012; Boulanger et al., 2013). Moreover, despite asynchronous fire years between the northern and southern sections of the transect, drought and temperature anomalies most likely synchronized interdecadal trends fire of activity at the regional scale (Gavin et al., 2006), as both sections experienced synchronous decadal burn rates and a similar influence of temperature and drought on large fires. Ultimately, this synchronizing top-down influence may have been forced by large-scale climate patterns driven by oceanic temperatures (Girardin et al., 2004; Le Goff et al., 2007).

This article is protected by copyright. All rights reserved. 
Despite the strong link between monthly climate and annual area burned, wildfire spread is in fact largely driven by day-to-day variation in weather following ignition (Abatzoglou and Kolden 2013). For example, the 2013 Eastmain fire, which is the second largest fire of our dataset, shows how a few days of extreme fire weather, characterized by strong winds and high temperatures had a disproportionate influence on area burned. In its early phase, the Eastmain fire progressively expanded across a large area of mature forest stands under relatively sustained severe fire weather and then spread very rapidly across any fuel types during two consecutive days of extremely severe fire weather conditions. Such extreme conditions probably contributed also to the spread of the largest fire of our dataset (1922 fire; $124 \mathrm{~km}$ ), as suggested by its 50-km overlap with the 1917 fire (fuel then aged 5 years) at km 135-185 (Fig. 3). Flat topography and prevailing winds parallel to rivers and landscape orientation (east-west) may have amplified the effect of weather during the development of these very large fires (Mansuy et al., 2014).

Despite strong top down influences of climate and weather, our study area is clearly an age-dependant stand-age mosaic (Fig. 1; Héon et al., 2014; Parisien et al., 2014; Parks et al., $2015,2016)$. In fact, the burn rate of $5.5 \% \mathrm{yr}^{-1}$ in forest stands older than 50 years during the $20^{\text {th }}$ century, compared to rates of $0-1.5 \% \mathrm{yr}^{-1}$ in stands of less than 20-years-old (Fig. 7a), indicates that the age-dependent resistance to fire activity is considerable and that an extremely high burn rates of $\sim 5 \% \mathrm{yr}^{-1}$ would have characterized our study region during the last century in absence of a fuel age effect. An overall burn rate of $5 \% \mathrm{yr}^{-1}$ would have been almost two times greater than the highest rates recently observed within the most fire-prone areas of the Canadian boreal zone (Boulanger et al., 2012). Although it has long been assumed that fires occur independently of forest age in the North American boreal forest (Bessie \& Johnson, 1995), our results clearly show that this is not always the case. 
Several phenomena can explain the strength of age-dependant resistance to fire. First, because of its high burn rate relative to the rate of postfire fuel recovery, our study area has been characterised by frequent encounter of immature fuels by spreading fires, thus increasing the strength of the age effect as compared to other regions of the North American boreal forest where no such effect was detected (Price et al., 2015). Second, although almost any fuel type can burn during extreme fire weather, as shown in the Eastmain fire and elsewhere in North America (Parks et al., 2015), such extreme conditions are rare by definition and do not occur during all fires or through the entire growth of a given fire event. For example, the extraordinarily rapid growth observed during the last stage of the Eastmain fire was triggered by one of the two sequences of two consecutive days with a FWI index value greater than 50 to have occurred since 1977 in the study area. Third, age-independent fire progression during extreme weather is in fact spatially dependant on prior age-dependant growth of the same fire during less extreme weather, as also evidenced by the early progression of the Eastmain fire (Fig. 6a). That a fire perimeter of more than $150 \mathrm{~km}$ was already active at the onset of the final sequence in 2013 permitted considerable fire growth during the following two days. Fourth, compared to other fuel types the flammability of mature conifers increases disproportionately with elevated temperature and drought, leading to the preferential development of large fires within large patches of mature conifers (Dash et al., 2016; Bernier et al., 2016). Fifth, fuel age is likely to influence not only fire spread but also ignition (Krawchuk et al., 2006). Finally, because fire is a spatially contagious phenomenon, fire-resistant landscape patches will not only reduce fire activity within their interior, but also outside their boundaries, creating a "fire shadow" (Finney, 2005; Parisien et al., 2010). 
In addition to the transient effect of forest age on landscape-level flammability, lakes and large peatlands represent additional bottom-up impediments to fire ignition and spread. Increasing lake and peatland abundance at distances of at least $2.5 \mathrm{~km}$ has considerably reduced fire recurrence within sampling cells (Fig. 7b). This effect has been most evident in the central section before the 2013 fire, demonstrating that large sectors can escape fire repeatedly, even within the most fire-prone regions of the boreal forest. It is well known that individual sites may escape fire (Wallenius et al., 2004; Cyr et al., 2005; Ouarmim et al., 2015) due to poor drainage conditions and high lake or wetland abundance in their surroundings (Hellberg et al., 2004; Cyr et al., 2005; Madoui et al., 2011; Barrett et al., 2013; Senici et al., 2015). These fire refuges, with their associated biodiversity and high carbon stocks are important features of these landscapes (Hornberg et al., 1998; Ouarmim et al., 2014). In our study area, the lack of fire eventually leads to jack pine exclusion and to the development of overmature spruce stands (LeGoff and Sirois, 2004)).

Because lakes and peatlands tend to promote the persistence of old forest stands, whereas stand age per se has the opposite effect, these two resistance mechanisms would have tended to mask each other's effect in our dataset. Thus, a stronger age-dependence of burn rates may have been documented in the absence of lakes and peatlands and a stronger wet area-dependence may have been detected in absence of stand age effect. For example, the apparent decrease of burn rates in forest stands more than 60 years old (Fig. 7a) probably reflects the tendency of these old stands to develop and persist in areas resistant to fire due to high lake and peatland cover. The alternative explanation that overmature spruce stands decrease in flammability is not supported by recent studies showing that these stands are positively selected by fire across the North American boreal forest (Bernier et al., 2016; Dash et al., 2016). 
Although interactions among lake and peatlands and stand age are probably spatially complex, collectively these factors would help identify areas at greater risk of burning (e.g. large forest patch more than 50-years-old containing few lakes and peatlands), as well as infrastructure exposure to fire in the current context of increasing fire activity. For example, the large sector that has escaped fire for several decades in the surroundings of the La Grande weather station at the northern end of the transect (Fig. 2) corresponds to an unusually persistent large area of old forests in the context of the last century (km 0-50 in Figs 3 and 8) and comprises several strategic hydroelectric infrastructures along with the towns of Chisasibi, Wemindji, and Radisson. Burn probability modelling using fire growth algorithms would help map fire likelihood around infrastructures, given the surrounding land physiography, hydrography and fuel types (Finney, 2005; Parisien et al., 2007).

Spatio-temporal variability vs. recent and future trends

Our study supports previous assertions that regions experiencing very large fires have inherently unstable fire regimes because fires are so large that no fraction of the total landscape can represent its entirety; that is, no section comprises the same age classes frequency distribution as the total landscape (Romme, 1982; Baker, 1989; Turner et al., 1993). Although a relatively stable age mosaic prevailed in the northern section of the study area during the $19^{\text {th }}$ century due to relatively small and regular fire events, large and irregular fires in the rest of our spatio-temporal domain clearly resulted in an unstable, oscillating landscape-age mosaic.

Consequently, because of high background variability, along with buffering of burn rates by bottom-up resistance, long records of fire size, fire intervals, and burn rates are necessary to determine if the recent warming trend has shifted the fire regime outside range of variability. For instance, even though it may be fairly exhaustive, the atlas of fire 
perimeters in Canada (1980-2013; Fig. 2) is too short to provide an adequate reference period. In addition, the increase of burn rates with temperatures may be altered by the confounding influence of precipitation and drought (Girardin and Muldesee, 2008). For example, although a rising trend of burn rates is evident in our study area (1980-2012), a similar interval of high burn rates occurred during the early $20^{\text {th }}$ century during a time period of relatively cold summer temperatures (Gennaretti et al., 2014; Naulier et al., 2014). Thus, even if recent burn rates of the study area have been rising to relatively high values compared to the rest of the North American boreal forest, this trend would have to continue for a few additional decades before we could confirm that recent warming has led to unprecedented burn rates.

However, by simultaneously considering the spatial and temporal dimensions, our study suggests that the forest-age mosaic may be outside its range of variability even if the main fire regime parameters (fire size, fire intervals, burn rates) are not. By allowing the 2013 fire to spread into an area previously resistant to fire due to its high lake and peatland cover, extremely severe fire weather has shifted the abundance of fire refuge outside its range of variability of the last 175 years (Fig. 8). Because large patches of old forest stands are unlikely to develop in these fire-prone regions without the sheltering effect of lakes and peatlands, they may be vulnerable to such severe weather. The directional erosion of these fire refuges at large spatial scale (ecological regions, province, biome) would be an early sign that new fire regimes and age mosaic are developing.

Future burn rates will continue to diverge from rates predicted based solely on climatic potential, although the intensity of this phenomenon is likely to vary with climate change. The predicted increase in the frequency of severe fire weather (Jolly et al., 2015; Wang et al., 
2015 ) is likely to weaken the age-dependant resistance to high burn rates. This is demonstrated by the abrupt progression of the Eastmain fire, as well as by the higher agespecific burn rates we observed when fire of the northern section where immense. It will be interesting to determine if the extreme conditions that characterized the last few days of 2013 Eastmain fire are increasing in frequency and, if so, how this may affect burn rates and the predictability of the boreal landscape.

\section{Acknowledgements:}

The authors wish to thank Pierre-Paul Dion, and Simon Williams for field and laboratory assistance and two reviewers for their constructive comments. This research was financially supported by NSERC, Hydro-Quebec, Ouranos, ArcticNet, the EnviroNorth training program and the Centre for Northern Studies.

\section{References}

Abatzoglou JT, Kolden CA (2011) Relative importance of weather and climate on wildfire growth in interior Alaska. International Journal of Wildland Fire, 20, 479.

Alaska Interagency Coordination Center (2016) Fire History In Alaska. Available at http://afsmaps.blm.gov/imf_firehistory/imf.jsp?site=firehistory. Accessed April 27, 2016 .

Ali AA, Blarquez O, Girardin MP et al. (2012) Control of the multimillennial wildfire size in boreal North America by spring climatic conditions. Proceedings of the National Academy of Sciences of the USA, 109, 20966-20970.

Baker WL (1989) Landscape ecology and nature reserve design in the Boundary Waters Canoe Area, Minnesota. Ecology, 70, 23-35.

This article is protected by copyright. All rights reserved. 
Balshi MS, Mcguire AD, Duffy P, Flannigan M, Walsh J, Melillo J (2009) Assessing the response of area burned to changing climate in western boreal North America using a Multivariate Adaptive Regression Splines (MARS) approach. Global Change Biology, 15, 578-600.

Barrett CM, Kelly R, Higuera PE, Hu FS (2013) Climatic and land cover influences on the spatiotemporal dynamics of Holocene boreal fire regimes. Ecology, 94, 389-402.

Bergeron Y, Gauthier S, Flannigan M, Kafka V (2004) Fire regimes at the transition between mixedwood and coniferous boreal forest in northwestern Quebec. Ecology, 85, 19161932.

Bergeron Y, Cyr D, Girardin MP, Carcaillet C (2011) Will climate change drive 21st century burn rates in Canadian boreal forest outside of its natural variability: collating global climate model experiments with sedimentary charcoal data. International Journal of Wildland Fire, 19, 1127-1139.

Bernier P, Gauthier S, Jean P-O, Manka F, Boulanger Y, Beaudoin A, Guindon L (2016) Mapping local effects of forest properties on fire risk across Canada. Forests, 7, 157.

Bessie WC, Johnson EA (1995) The relative importance of fuels and weather on fire behavior in subalpine forests. Ecology, 76, 747-762.

Bond-Lamberty B, Wang C, Gower ST (2004) Net primary production and net ecosystem production of a boreal black spruce wildfire chronosequence. Global Change Biology, $10,473-487$.

Bond-Lamberty B, Peckham SD, Ahl DE, Gower ST (2007) Fire as the dominant driver of central Canadian boreal forest carbon balance. Nature, 450, 89-92.

Boulanger Y, Gauthier S, Burton PJ, Vaillancourt M-A (2012) An alternative fire regime zonation for Canada. International Journal of Wildland Fire, 21, 1052-1064.

This article is protected by copyright. All rights reserved. 
Boulanger Y, Gauthier S, Gray DR, Le Goff H, Lefort P, Morissette J (2013) Fire regime zonation under current and future climate over eastern Canada. Ecological Applications, 23, 904-923.

Boulanger Y, Gauthier S, Burton PJ (2014) A refinement of models projecting future Canadian fire regimes using homogeneous fire regime zones. Canadian Journal of Forest Research, 44, 365-376.

Brown CD, Johnstone JF (2011) How does increased fire frequency affect carbon loss from fire? A case study in the northern boreal forest. International Journal of Wildland Fire, 20, 829-837.

Canadian Forest Service (2016) Canadian Wildland Fire Information System. Available at http://cwfis.cfs.nrcan.gc.ca/datamart. Accessed April 27, 2016.

Cavard X, Boucher J-F, Bergeron Y (2015) Vegetation and topography interact with weather to drive the spatial distribution of wildfires in the eastern boreal forest of Canada. International Journal of Wildland Fire, 24, 391-406

Cyr D, Bergeron Y, Gauthier S, Larouche AC (2005) Are the old-growth forests of the Clay Belt part of a fire-regulated mosaic? Canadian Journal of Forest Research, 35, 65-73.

Dash CB, Fraterrigo JM, Hu FS (2016) Land cover influences boreal-forest fire responses to climate change: geospatial analysis of historical records from Alaska. Landscape Ecology, DOI 10.1007/s10980-016-0361-2

Duffy PA, Walsh JE, Graham JM, Mann DH, Rupp TS (2005) Impacts of large-scale atmospheric-ocean variability on Alaskan fire season severity. Ecological Applications, 15, 1317-1330.

Environnement Canada (2016) Canadian climate normals or averages 1981-2010. http://climate.weather.gc.ca/climate_normals/index_e.html. Accessed April 27, 2016. 
Finney MA (2005) The challenge of quantitative risk analysis for wildland fire. Forest Ecology and Management, 211, 97-108.

Flannigan M, Wotton B (1991) Lightning-ignited forest fires in northwestern Ontario.

Canadian Journal of Forest Research, 21, 277-287.

Flannigan M, Wotton B (2001) Climate, weather, and area burned. Forest fires. New York: Academic Press. p, 351, 73.

Flannigan MD, Logan KA, Amiro BD, Skinner WR, Stocks BJ (2005) Future Area Burned in Canada. Climatic Change, 72, 1-16.

Gavin DG, Hu FS, Lertzman K, Corbett P (2006) Weak climatic control of stand-scale fire history during the late Holocene. Ecology, 87, 1722-1732.

Gennaretti F, Arseneault D, Nicault A, Perreault L, Bégin Y (2014) Volcano-induced regime shifts in millennial tree-ring chronologies from northeastern North America. Proceedings of the National Academy of Sciences of the USA, 11, 13888-13893.

Girardin M, Tardif J, Flannigan M, Bergeron Y (2004) Multicentury reconstruction of the Canadian Drought Code from eastern Canada and its relationship with paleoclimatic indices of atmospheric circulation. Climate Dynamics, 23, 99-115.

Girardin MP, Mudelsee M (2008) Past and future changes in Canadian boreal wildfire activity. Ecological Applications, 18, 391-406.

Girardin MP, Wotton BM (2009) Summer Moisture and Wildfire Risks across Canada. Journal of Applied Meteorology and Climatology, 48, 517-533.

Harris I, Jones P, Osborn T, Lister D (2014) Updated high- resolution grids of monthly climatic observations-the CRU TS3.10 Dataset. International Journal of Climatology, 34, 623-642.

This article is protected by copyright. All rights reserved. 
Hellberg E, Niklasson M, Granström A (2004) Influence of landscape structure on patterns of forest fires in boreal forest landscapes in Sweden. Canadian Journal of Forest Research, 34, 332-338.

Hély C, Fortin CM-J, Anderson KR, Bergeron Y (2010) Landscape composition influences local pattern of fire size in the eastern Canadian boreal forest: role of weather and landscape mosaic on fire size distribution in mixedwood boreal forest using the Prescribed Fire Analysis System. International Journal of Wildland Fire, 19, 10991109.

Héon J, Arseneault D, Parisien M-A (2014) Resistance of the boreal forest to high burn rates. Proceedings of the National Academy of Sciences of the USA, 111, 13888-13893.

Holmes RL (1983) Computer-assisted quality control in tree-ring dating and measurement. Tree-Ring Bulletin, 43, 69-78.

Hornberg G, Zackrisson O, Segerstrom U, Svensson BW, Ohlson M, Bradshaw RH (1998) Boreal swamp forests. BioScience, 48, 795-802.

Irulappa Pillai Vijayakumar DB, Raulier F, Bernier P, Paré D, Gauthier S, Bergeron Y, Pothier D (2016) Cover density recovery after fire disturbance controls landscape aboveground biomass carbon in the boreal forest of eastern Canada. Forest Ecology and Management, 360, 170-180.

Johnstone JF, Hollingsworth TN, Chapin FS, Mack MC (2010) Changes in fire regime break the legacy lock on successional trajectories in Alaskan boreal forest. Global Change Biology, 16, 1281-1295.

Johnstone JF, Rupp TS, Olson M, Verbyla D (2011) Modeling impacts of fire severity on successional trajectories and future fire behavior in Alaskan boreal forests. Landscape Ecology, 26, 487-500.

This article is protected by copyright. All rights reserved. 
Jolly WM, Cochrane MA, Freeborn PH, Holden ZA, Brown TJ, Williamson GJ, Bowman DM (2015) Climate-induced variations in global wildfire danger from 1979 to 2013. Nature Communications, 6, 7537.

Kasischke ES, Turetsky MR (2006) Recent changes in the fire regime across the North American boreal region - spatial and temporal patterns of burning across Canada and Alaska. Geophysical Research Letters, 33, L09703.

Kelly R, Chipman ML, Higuera PE, Stefanova I, Brubaker LB, Hu FS (2013) Recent burning of boreal forests exceeds fire regime limits of the past 10,000 years. Proceedings of the National Academy of Sciences of the USA, 110, 13055-13060.

Kettridge N, Turetsky M, Sherwood J et al. (2015) Moderate drop in water table increases peatland vulnerability to post-fire regime shift. Scientific Reports, 5, 8063.

Krawchuk M, Cumming S, Flannigan M, Wein R (2006) Biotic and abiotic regulation of lightning fire initiation in the mixedwood boreal forest. Ecology, 87, 458-468.

Lavoie L, Sirois L (1998) Vegetation changes caused by recent fires in the northern boreal forest of eastern Canada. Journal of Vegetation Science, 9, 483-492.

LeGoff H, Sirois L (2004) Black spruce and jack pine dynamics simulated under varying fire cycles in the northern boreal forest of Quebec, Canada. Canadian Journal of Forest Research, 34, 2399-2409.

Le Goff H, Flannigan MD, Bergeron Y, Girardin MP (2007) Historical fire regime shifts related to climate teleconnections in the Waswanipi area, central Quebec, Canada. International Journal of Wildland Fire, 16, 607-618.

Mack MC, Bret-Harte MS, Hollingsworth TN, Jandt RR, Schuur EA, Shaver GR, Verbyla DL (2011) Carbon loss from an unprecedented Arctic tundra wildfire. Nature, 475, 489-492.

This article is protected by copyright. All rights reserved. 
Madoui A, Leduc A, Gauthier S, Bergeron Y (2011) Spatial pattern analyses of post-fire residual stands in the black spruce boreal forest of western Quebec. International Journal of Wildland Fire, 19, 1110-1126.

Mansuy N, Gauthier S, Robitaille A, Bergeron Y (2011) The effects of surficial depositdrainage combinations on spatial variations of fire cycles in the boreal forest of eastern Canada. International Journal of Wildland Fire, 19, 1083-1098.

Mansuy N, Boulanger Y, Terrier A, Gauthier S, Robitaille A, Bergeron Y (2014) Spatial attributes of fire regime in eastern Canada: influences of regional landscape physiography and climate. Landscape Ecology, 29, 1157-1170.

Natural Ressource Canada (2006) National Topographic Database. Government of Canada, Centre for Topographic Information, Sherbrooke, Quebec, Canada.

Naulier M., M.M. Savard, C. Bégin, D. Arseneault, J. Marion, Gennaretti, F., A. Nicault, Y. Bégin. 2015. A millennial summer temperature reconstruction for Northeastern Canada using isotopes in subfossil trees. Climate of the Past, 11, 1153-1164.

Niklasson M, Granström A (2000) Numbers and sizes of fires: long-term spatially explicit fire history in a Swedish boreal landscape. Ecology, 81, 1484-1499.

O’Donnell AJ, Boer MM, McCaw WL, Grierson PF (2011) Vegetation and landscape connectivity control wildfire intervals in unmanaged semi- arid shrublands and woodlands in Australia. Journal of Biogeography 38,112-124.

Oris F, Asselin H, Finsinger W et al. (2014) Long-term fire history in northern Quebec: implications for the northern limit of commercial forests. Journal of Applied Ecology, 51, 675-683.

Ouarmim S, Asselin H, Bergeron Y, Ali AA, Hély C (2014) Stand structure in fire refuges of the eastern Canadian boreal mixedwood forest. Forest Ecology and Management, 324, $1-7$.

This article is protected by copyright. All rights reserved. 
Ouarmim S, Ali AA, Asselin H, Hély C, Bergeron Y (2015) Evaluating the persistence of post- fire residual patches in the eastern Canadian boreal mixedwood forest. Boreas, 44, 230-239.

Parisien M-A, Junor DR, Kafka VG (2007) Comparing landscape-based decision rules for placement of fuel treatments in the boreal mixedwood of western Canada. International Journal of Wildland Fire, 16, 664-672.

Parisien M-A, Miller C, Ager AA, Finney MA (2010) Use of artificial landscapes to isolate controls on burn probability. Landscape Ecology, 25, 79-93.

Parisien M-A, Parks SA, Miller C, Krawchuk MA, Heathcott M, Moritz MA (2011) Contributions of Ignitions, Fuels, and Weather to the Spatial Patterns of Burn Probability of a Boreal Landscape. Ecosystems, 14, 1141-1155.

Parisien M-A, Parks SA, Krawchuk MA, Little JM, Flannigan MD, Gowman LM, Moritz MA (2014) An analysis of controls on fire activity in boreal Canada: comparing models built with different temporal resolutions. Ecological Applications, 24, 13411356.

Parks SA (2014) Mapping day-of-burning with coarse-resolution satellite fire-detection data. International Journal of Wildland Fire, 23, 215-223.

Parks SA, Holsinger LM, Miller C, Nelson CR (2015) Wildland fire as a self-regulating mechanism: the role of previous burns and weather in limiting fire progression. Ecological Applications, 25, 1478-1492.

Parks SA, Miller C, Holsinger LM, Baggett LS, Bird BJ (2016) Wildland fire limits subsequent fire occurrence. International Journal of Wildland Fire, DOI : 10.1071/WF15107.

Payette S, Morneau C, Sirois L, Desponts M (1989) Recent fire history of the northern Quebec biomes. Ecology, 70, 656-673. 
Payette S (1992) Fire as a controlling process in the North American boreal forest. In 'A systems analysis of the boreal forest'.(Eds HH Shugart, R Leemans, GB Bonan) pp. 144-169. pp Page, Cambridge University Press: Cambridge, UK.

Price OF, Bradstock RA (2010) The effect of fuel age on the spread of fire in sclerophyll forest in the Sydney region of Australia. International Journal of Wildland Fire 19, 35-45.

Price OF, Pausas JG, Govender N, Flannigan M, Fernandes PM, Brooks ML, Bird RB (2015) Global patterns in fire leverage: the response of annual area burnt to previous fire. International Journal of Wildland Fire 24, 297-306.

Rogers BM, Soja AJ, Goulden ML, Randerson JT (2015) Influence of tree species on continental differences in boreal fires and climate feedbacks. Nature Geoscience, $\mathbf{8}$, $228-234$

Romme WH (1982) Fire and landscape diversity in subalpine forests of Yellowstone National Park. Ecological Monographs, 52, 199-221.

SCIEM, 2011. PAST4 Personal Analysis System for Tree ring Research, version 4.3 Instruction Manual. Vienna

Senici D, Chen HYH, Bergeron Y, Ali AA (2015) The effects of forest fuel connectivity on spatiotemporal dynamics of Holocene fire regimes in the central boreal forest of North America. Journal of Quaternary Science, 30, 365-375.

Sirois L (1995) Initial phase of postfire forest regeneration in two lichen woodlands of northern Québec. Ecoscience, 2, 177-183.

St-Pierre H, Gagnon R, Bellefleur P (1992) Régénération après feu de l'épinette noire (Picea mariana) et du pin gris (Pinus banksiana) dans la forêt boréale, Québec. Canadian Journal of Forest Research, 22, 474-481.

Stocks BJ, Mason JA, Todd JB et al. (2002) Large forest fires in Canada, 1959-1997. Journal of Geophysical Research, 108, D1-8149.

This article is protected by copyright. All rights reserved. 
Stockwell C, Mcglynn J, Emslie R et al. (1968) Géologie du bouclier canadien. Géologie et Ressources Minérales du Canada, Partie A. Commission géologique du Canada, Ottawa, Ont.

Taylor AR, Chen HYH (2011) Multiple successional pathways of boreal forest stands in central Canada. Ecography, 34, 208-219.

Turetsky MR, Kane ES, Harden JW, Ottmar RD, Manies KL, Hoy E, Kasischke ES (2011) Recent acceleration of biomass burning and carbon losses in Alaskan forests and peatlands. Nature Geoscience, 4, 27-31.

Turner MG, Romme WH, Gardner RH, O'neill RV, Kratz TK (1993) A revised concept of landscape equilibrium: disturbance and stability on scaled landscapes. Landscape Ecology, 8, 213-227.

Van Wagner C (1987) Development and structure of the Canadian forest fire weather index system. Forestry Technical Report 35. Canadian Forest Service, Ottawa, Canada.

Wallenius TH, Kuuluvainen T, Vanha-Majamaa I (2004) Fire history in relation to site type and vegetation in Vienansalo wilderness in eastern Fennoscandia, Russia. Canadian Journal of Forest Research, 34, 1400-1409.

Wang X, Parisien M-A, Flannigan MD, Parks SA, Anderson KR, Little JM, Taylor SW (2014) The potential and realized spread of wildfires across Canada. Global Change Biology, 20, 2518-2530.

Wang X, Thompson D, Marshall G, Tymstra C, Carr R, Flannigan M (2015) Increasing frequency of extreme fire weather in Canada with climate change. Climatic Change, 130, 573-586.

Westerling AL, Turner MG, Smithwick EAH, Romme WH, Ryan MG (2011) Continued warming could transform Greater Yellowstone fire regimes by mid-21st century. Proceedings of the National Academy of Sciences of the USA, 108, 13165-13170.

This article is protected by copyright. All rights reserved. 
White PS, Pickett STA (1985) Natural disturbance and patch dynamics: An introduction. In:

The ecology of natural disturbance and patch dynamics. (ed White PS, Pickett STA) pp 3-13., Academic Press.

\section{Figure captions:}

Fig. 1: Properties of the landscape age mosaic across boreal landscapes under the contrasted scenarios of age-dependant vs. age-independent fire activity. Red arrow: top-down forcing of fire activity; blue arrow: bottom-up negative feedback caused by the age-dependant probability of burning. The two boxes display emergent properties of each scenario.

Fig. 2: Map of the study area within the North American boreal forest. (a) : Burn rates (\% of land area per year) were computed for $100 \mathrm{~km}$ x $100 \mathrm{~km}$ cells, according to fires recorded in Alaska and Canada between 1980 and 2012 (Alaska Interagency Coordination Center, 2016; Canadian Forest Service, 2016). (b) Fire polygons of the 1980-2013 time period, showing also overlaps (dark gray) and the location of the study transect (black: initially sampled by Héon et al., 2014; red : 75 new 2-km² cells sampled in this study). The 2013 Eastmain fire is shown in yellow.

Fig. 3: Fire occurrence in space and time along the study transect, with delineation of the three transect sections: northern, central (vertical gray bar), and southern. (a): Spatiotemporal patterns of fire length and fire intervals along the transect. Each horizontal dash represents a fire detected inside a $2-\mathrm{km}^{2}$ cell. (b): Number of fires detected into each sampling cell over the 1840-2013 time period. The 2013 Eastmain fire (E13; km130-234) is also indicated in (a).

This article is protected by copyright. All rights reserved. 
Fig. 4: Variability of burn rates and resulting landscape age structure along the transect over the 1840-2014 time period (a, b, c). Burn rates (d) are computed from total lengths burned within the corresponding transect sections using a 25-years moving window and are plotted for the last year of each 25-year interval.

Fig. 5: Superposed epoch analysis of gridded monthly temperatures data from the CRU 3.21 dataset (1901-2012) and associated Monthly Drought Code (MDC) in relation with positive or negative lags from fire years. Only years with length burned equal or greater than $10 \mathrm{~km}$ are considered for both the northern $(a ; n=8)$ and southern sections $(b ; n=10)$. Solid and dashed horizontal lines display the $99 \%$ and $95 \%$ confidence intervals estimated by bootstrapping and black and gray columns correspond to values outside the $99 \%$ and $95 \%$ CIs, respectively. Superposed epoch analysis of precipitation data is shown in the Fig S4.

Fig. 6: Daily spread of the 2013 Eastmain fire relative to previous fires as reconstructed from MODIS data. Panels refer to the stand-age mosaic before the fire (a), the fire progression before July 3 (b), and the sequence of abrupt expansion (c) across young fuels and the fire refuge of the central transect section (black line near the SE fire border) during the extreme fire weather event of July 3-4 (see also the Fig. S6).

Fig. 7: Bottom-up resistance to high burn rates along the transect over the 1840-2014 time period. (a) age-dependant resistance evidenced by age-specific burn rates for three spatiotemporal sub-domains with contrasting fire lengths and burn rates. For a given sub-domain and age-class, the burn rate is computed from the ratio of fire interval over time since previous fire frequency distributions (see Fig. S7). Error bars correspond to bootstrapped 95\% confidence intervals. (b) Resistance due to wet areas around sampling cells. Median cover of lakes and peatlands (\% of total landscape) within $2.5 \mathrm{~km}$ buffers around cells is 
plotted against the number of fire recorded into cells. Error bars display the $95 \%$ confidence intervals of the median estimated by bootstrapping.

Fig. 8: Time since previous fire along the transect immediately before (blue line) and after (red line) the most important fire years $(1847,1922,1941,1989,2013)$ since 1840. The 1882 fire (length burned $=29.8 \mathrm{~km}$ ) was also considered as a mid-point during the long interval between the 1847 and 1922 fires. The vertical gray bar highlights the central section. Time since previous fire is underestimated within the central section for all depicted years except 2014 due to the lack of fire scars in the corresponding sampling cells (Fig. S1).

Table 1: Fire activity of the three transect sections during the 1840-2013 time period.

\begin{tabular}{lccc}
\hline & Northern & Central & Southern \\
\hline Total length $(\mathrm{km})$ & 210.2 & 28.0 & 102.0 \\
Total length burned $(\mathrm{km})$ & 789.7 & 40.0 & 420.0 \\
Ratio length burned / zone length & 3.8 & 1.4 & 4.1 \\
Number of fire years & 36 & 4 & 27 \\
Longest fire (km ; year) & $118.2 ; 1922$ & $24.0 ; 2013$ & $56.0 ; 1847$ \\
Burn rate 1840-2013 (\% land area $\left.\mathrm{yr}^{-1}\right)$ & 2.2 & 0.8 & 2.4 \\
Burn rate 1840-1910 (\% land area $\left.\mathrm{yr}^{-1}\right)$ & 1.4 & 0.4 & 2.0 \\
Burn rate 1911-2013 (\% land area $\left.\mathrm{yr}^{-1}\right)$ & 2.7 & 1.1 & 2.6 \\
\hline
\end{tabular}

This article is protected by copyright. All rights reserved. 


\section{Supporting information:}

Table S1. Comparison of stems sampled in this study with the study of Héon et al. (2014).

Figure S1: Reconstruction of fire length from fire scars and first tree rings in the 75 cells along the southern extension of the road transect.

Figure S2: Cumulative frequency distributions of fire length and fire intervals for the entire transect over the 1840-2014 time period.

Figure S3: Scatterplot of length burned for a given year in the southern section as a function of length burned in the northern section between 1840 and 2013.

Figure S4: Superposed epoch analysis of gridded monthly precipitation data from the CRU 3.21 dataset (1901-2012) in relation with positive or negative lags from fire years.

Figure S5: Superposed epoch analysis of gridded climate data from the CRU 3.21 dataset (1901-2012) in relation with positive or negative lags from fire years with distance burned $<10 \mathrm{~km}$ along the entire transect.

Figure S6: Time series of Fire Weather Index values from the La Grande weather station and cumulated area burned during the 2013 summer, emphasising the activity period of the Eastmain fire and the extreme fire weather of July 3-4.

Figure S7: Frequency distributions of all time since previous fire that have occurred along the transect and frequency distributions of all fire intervals that ended during each time period. 


\section{Climate and weather}

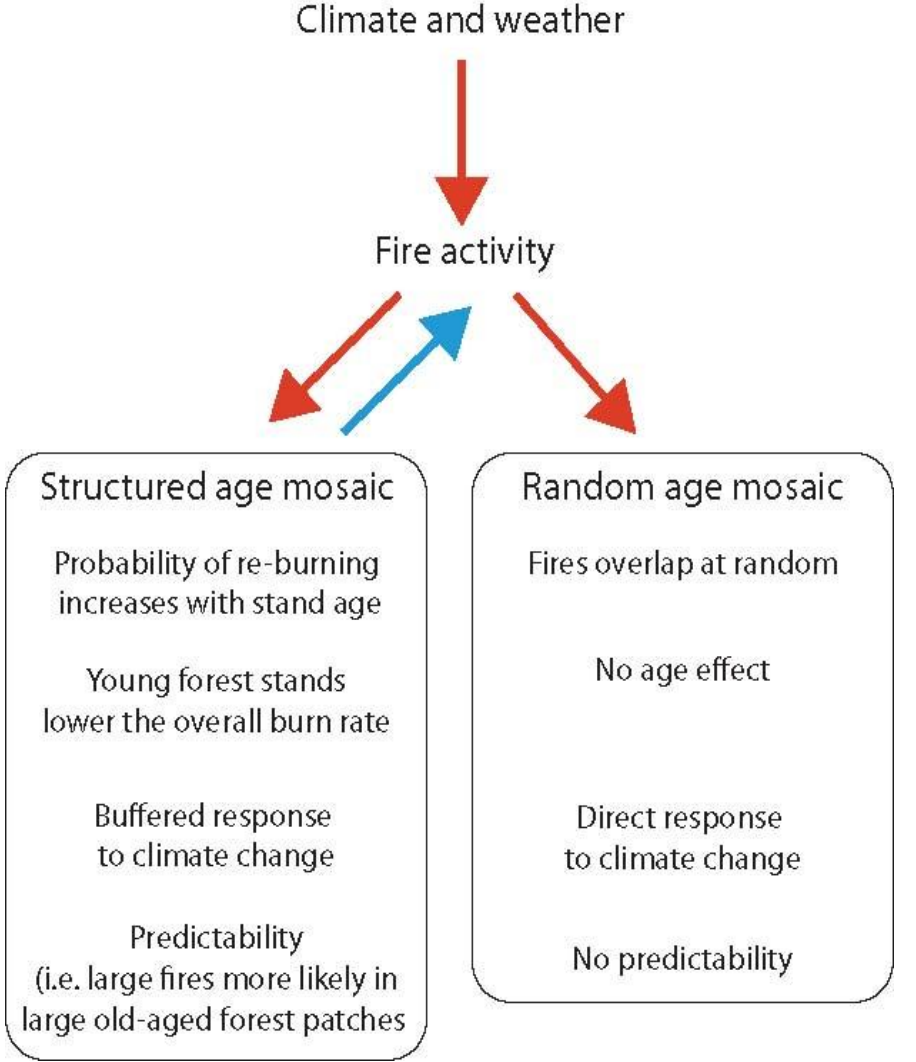

This article is protected by copyright. All rights reserved. 


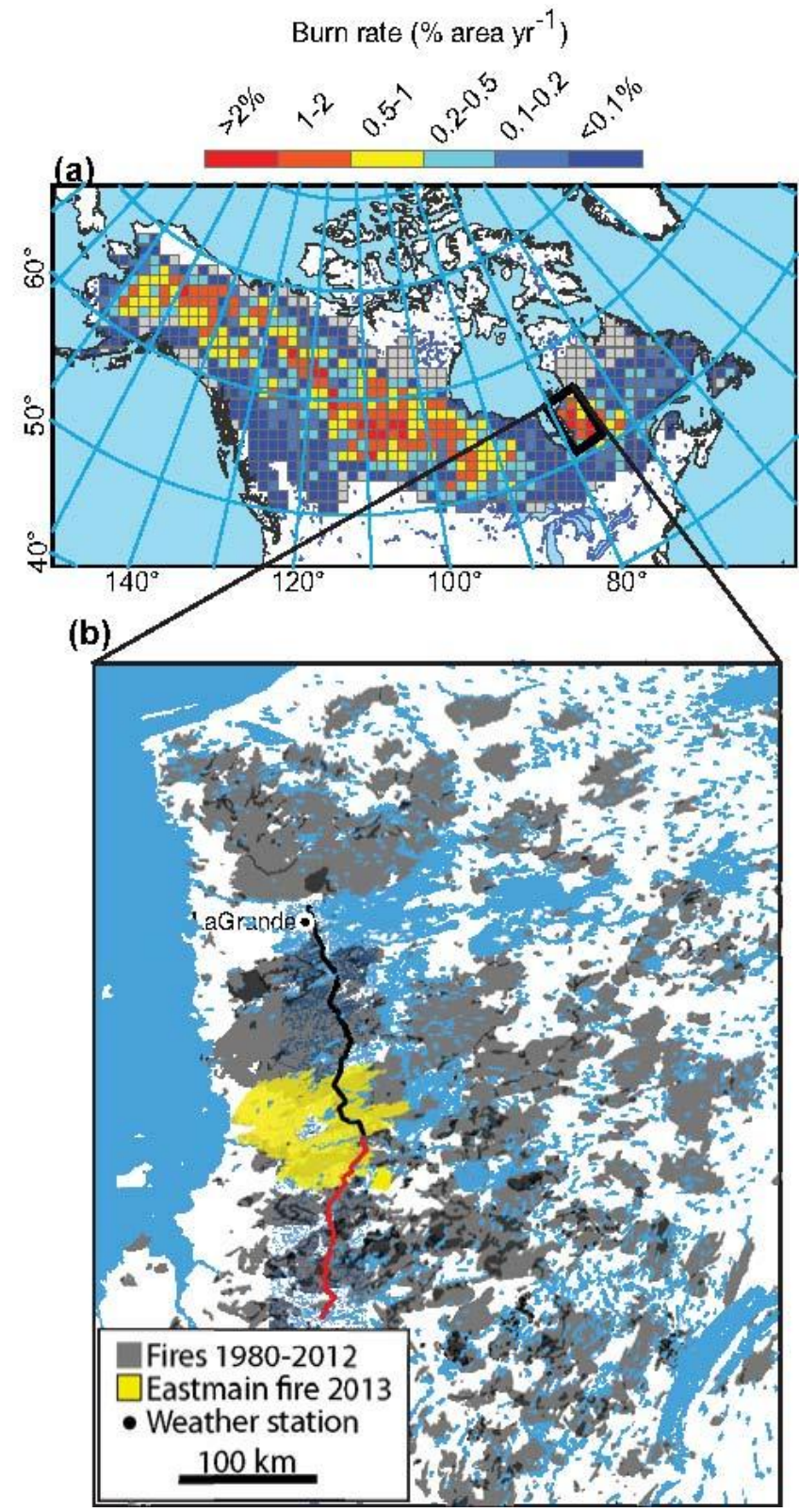

This article is protected by copyright. All rights reserved. 


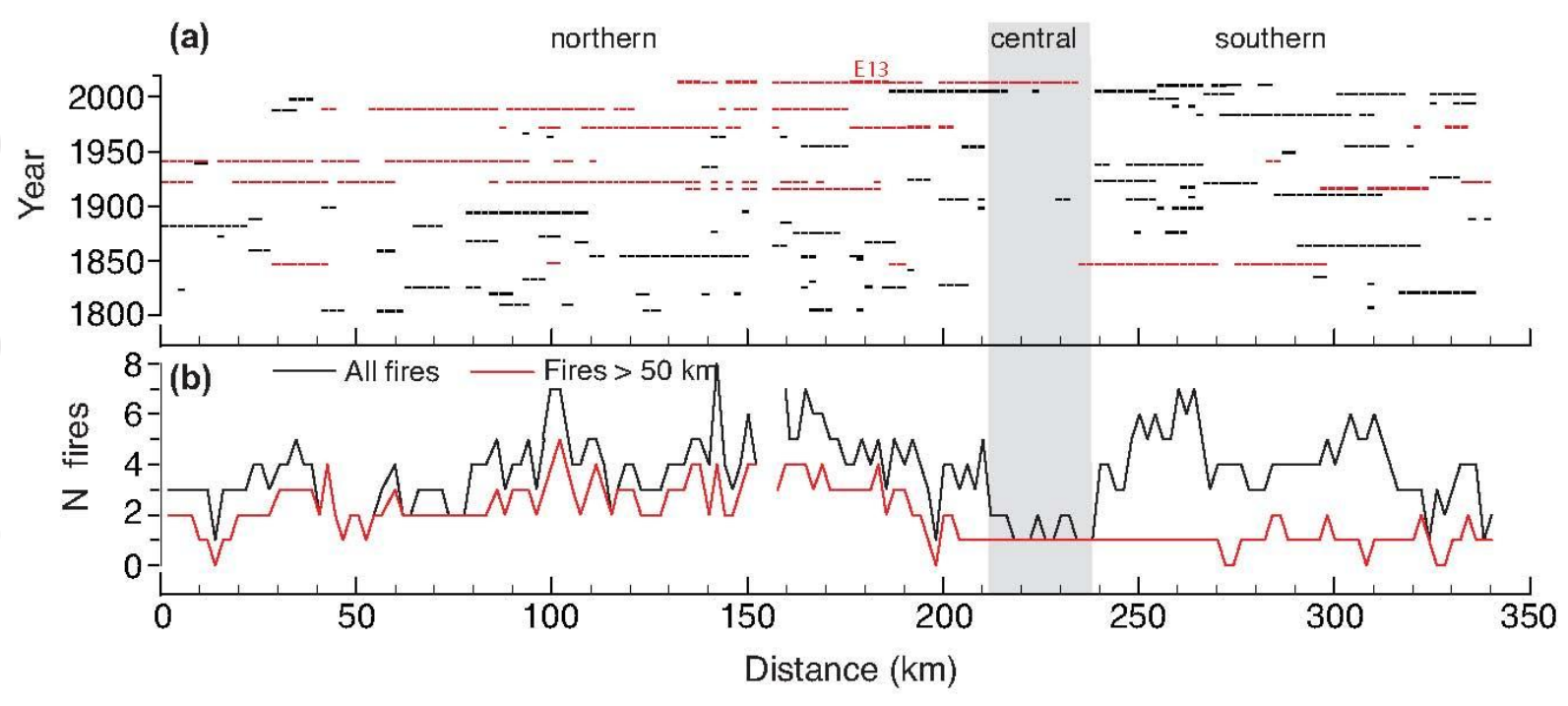

This article is protected by copyright. All rights reserved. 


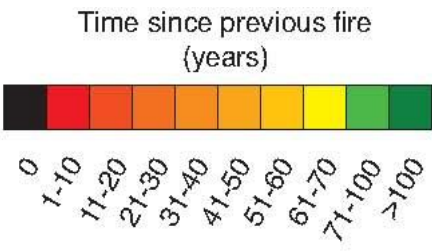

(a) Northern section $(210.2 \mathrm{~km})$
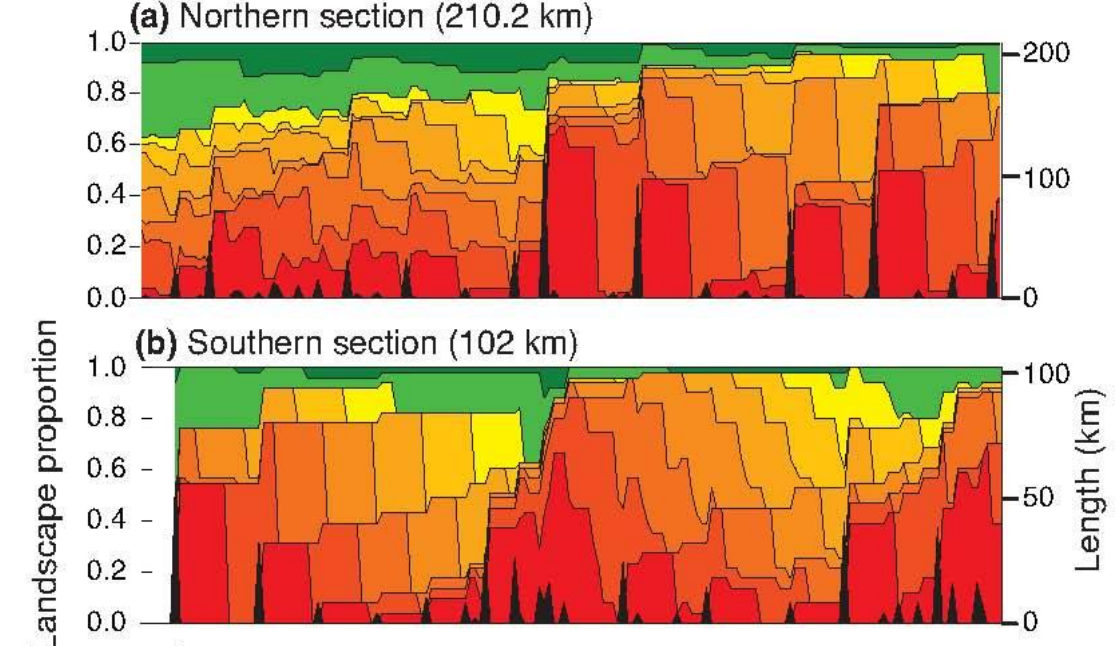

. (c) Entire transect $(340.2 \mathrm{~km})$

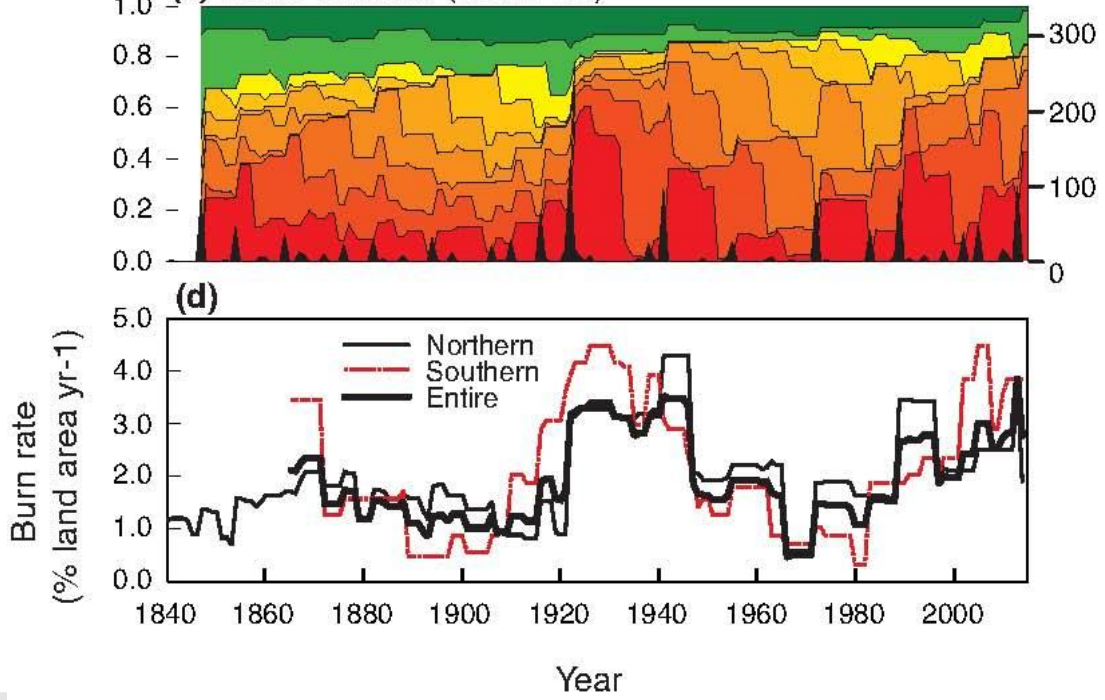

This article is protected by copyright. All rights reserved. 
(a) Northern section
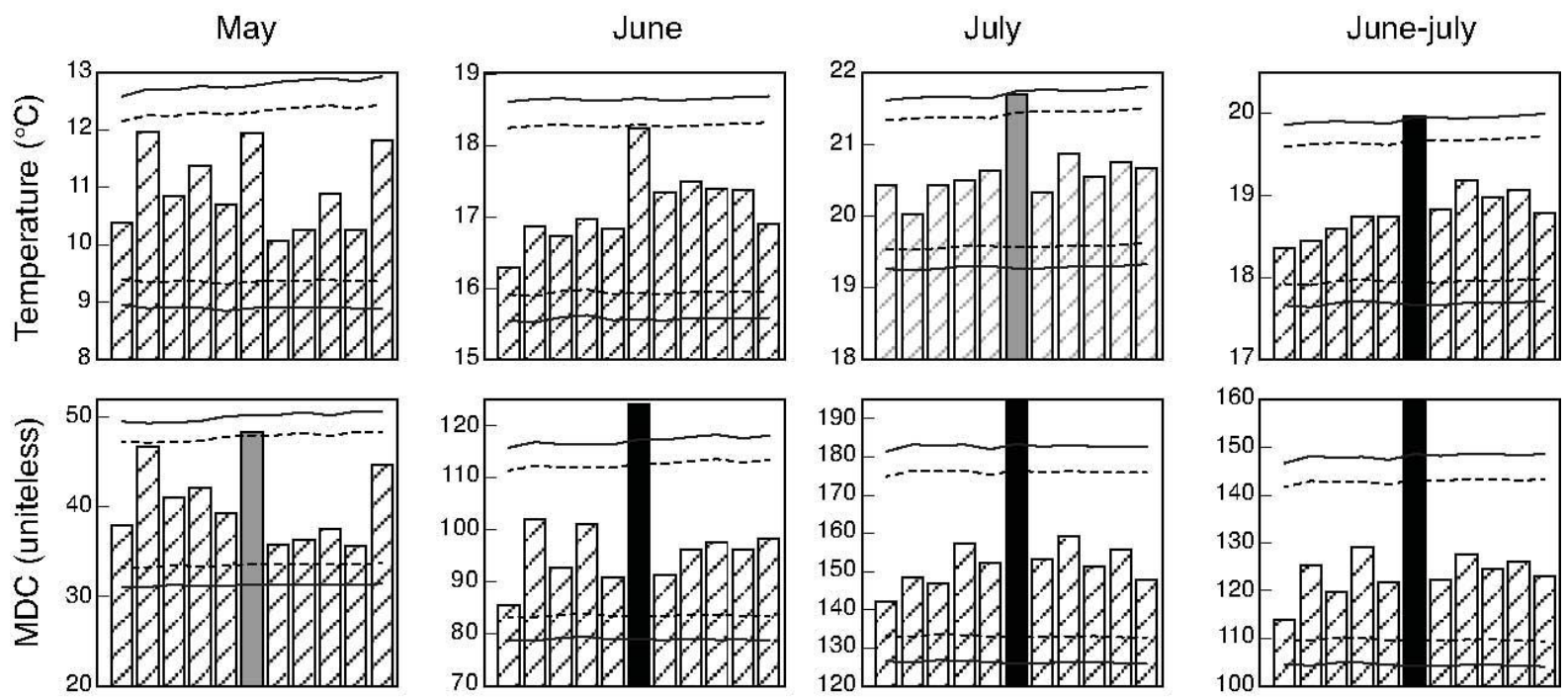

(b) Southern section
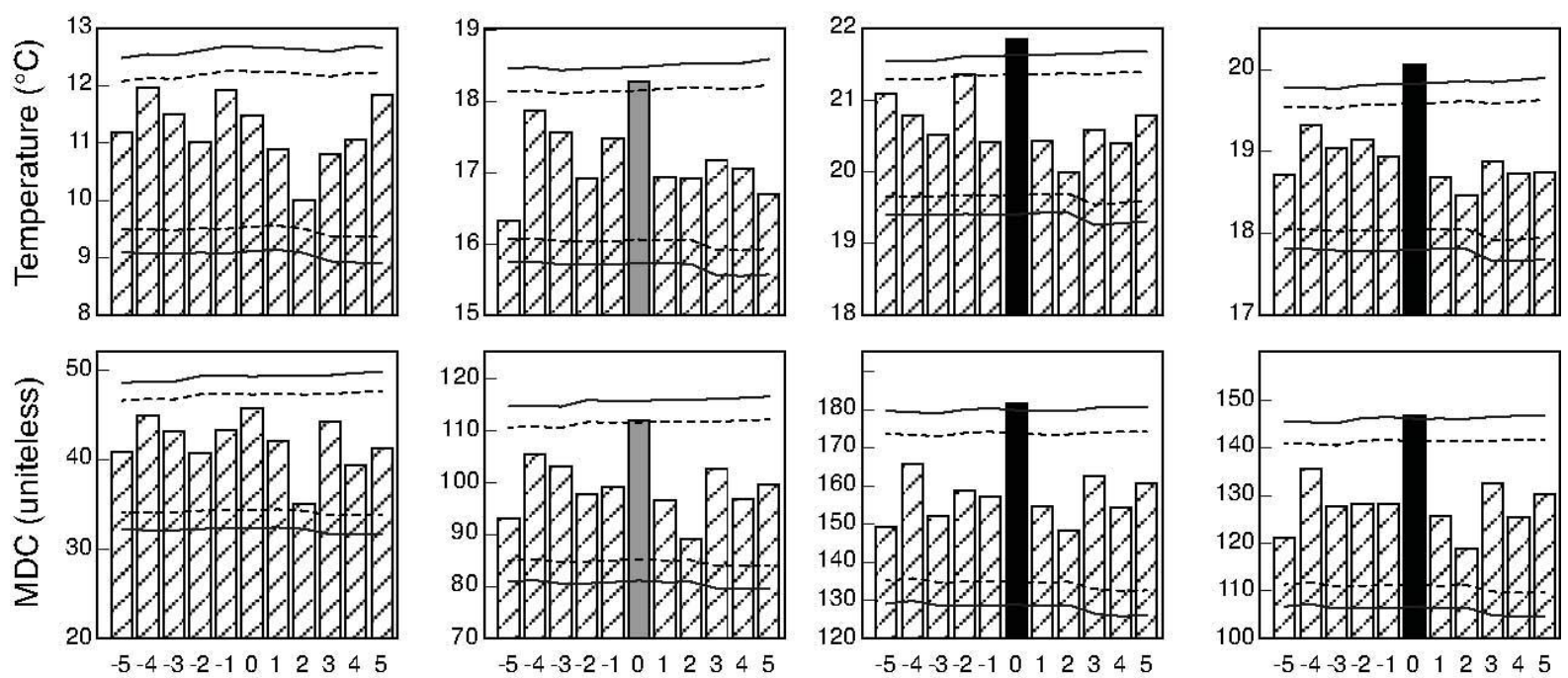

Lag from fire year (years)

This article is protected by copyright. All rights reserved. 
(a)

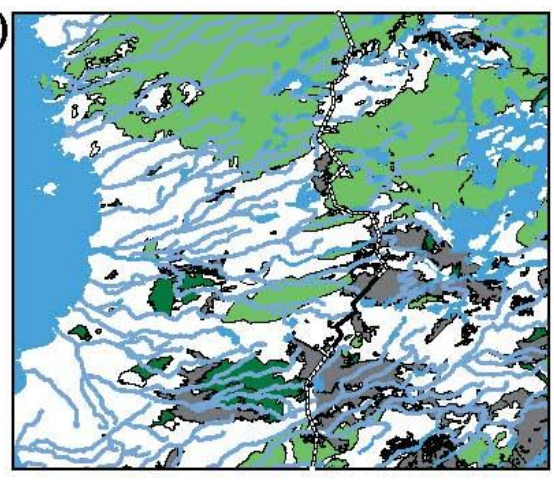

(b)

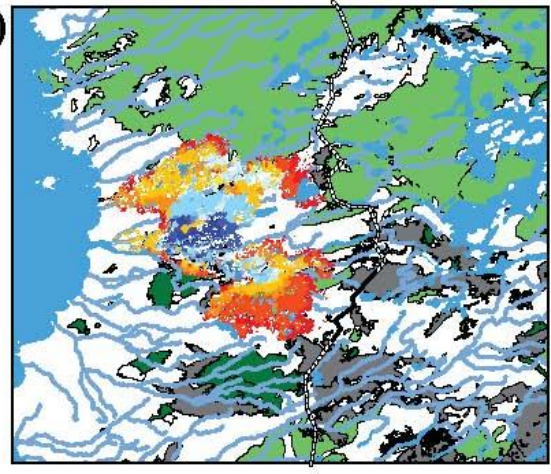

(c)

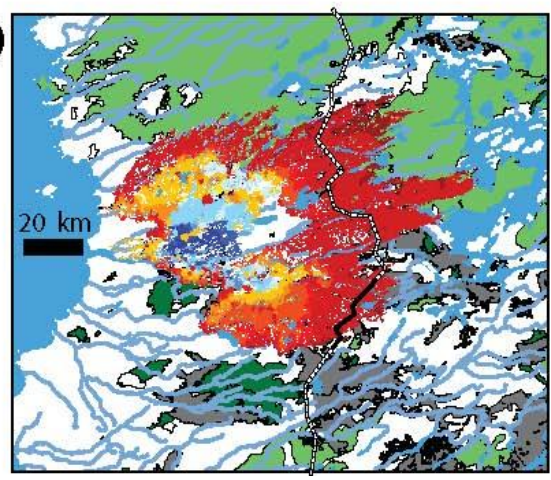

Previous fires

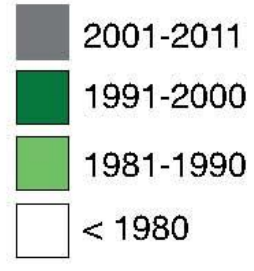

2013 fire

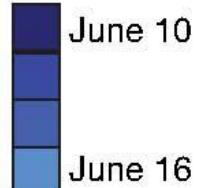

June 22

June 28

July 4

This article is protected by copyright. All rights reserved. 

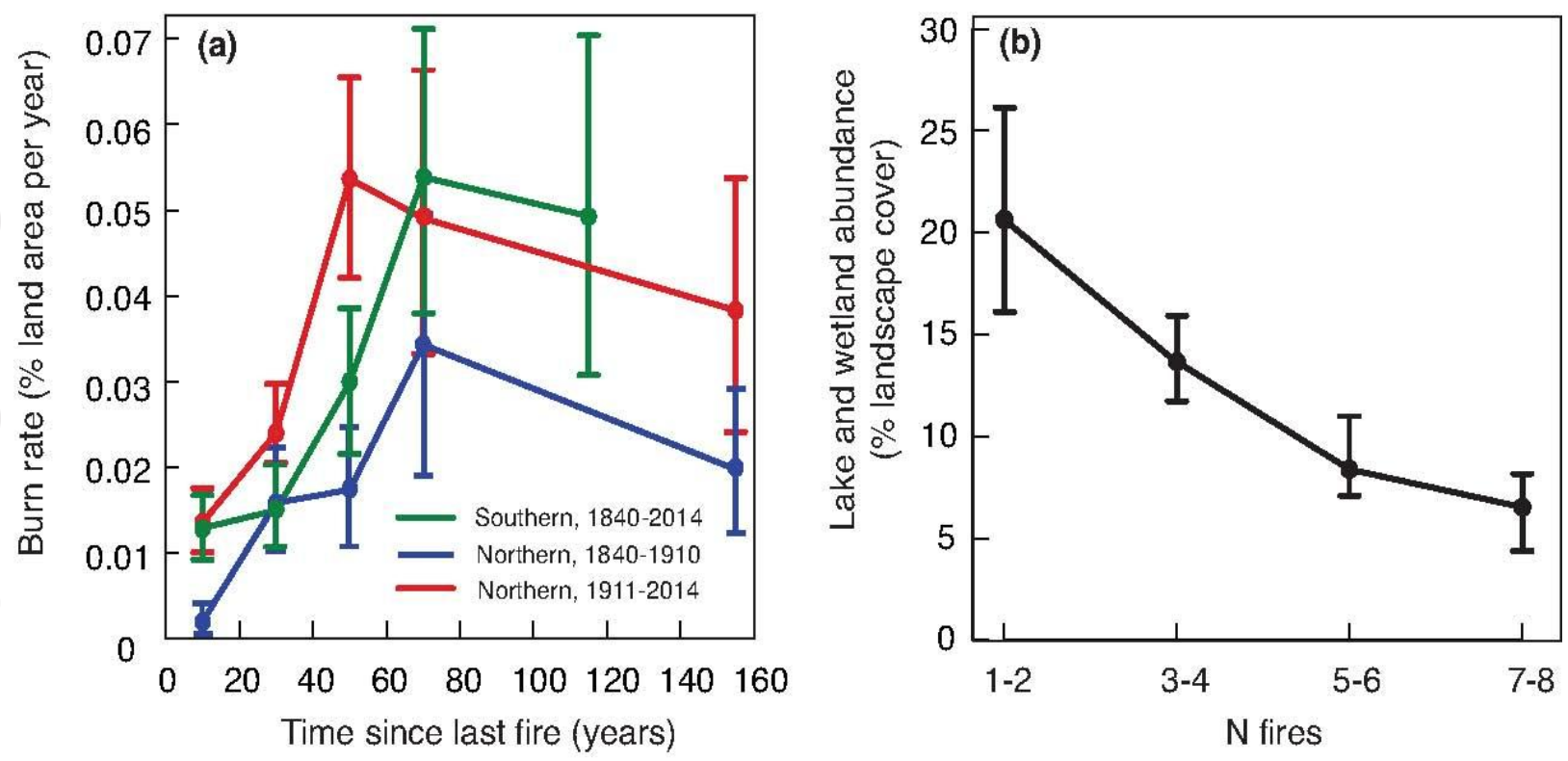

This article is protected by copyright. All rights reserved. 


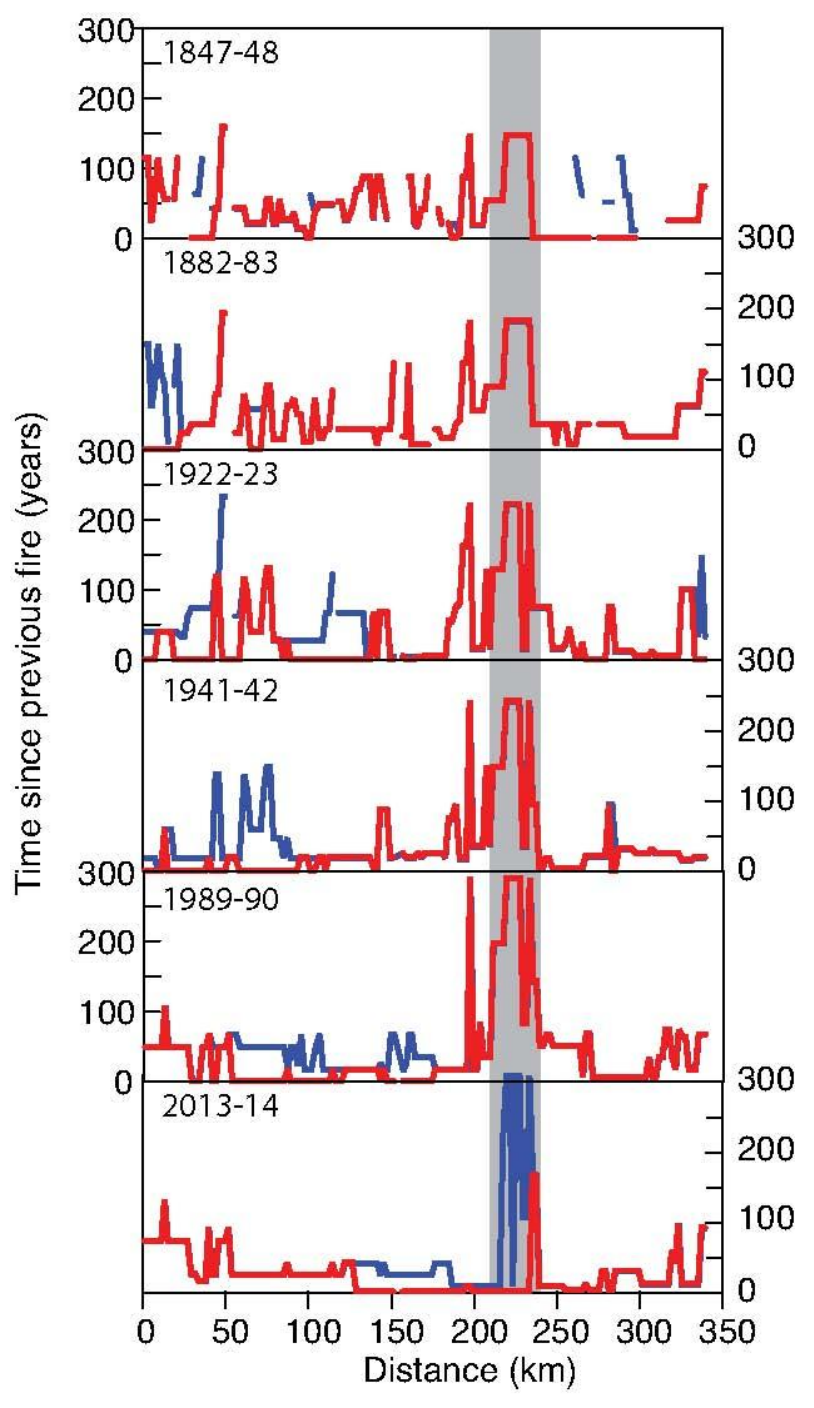

This article is protected by copyright. All rights reserved. 